\section{Sacroplasty: Report of Three Cases}

\section{Sakroplasti: Üc̣ Olgu Bildirimi}

\begin{abstract}
AIM: Sacral stress fractures are rare fractures presenting themselves with low back and groin pain. These fractures can be treated effectively using sacroplasty.

MATERIAL and METHODS: The clinical and radiological data of three cases that underwent sacroplasty for sacral stress fractures were reviewed. The pain severity was assessed using the VAS system. The radiological investigation was performed using sacral CT and MRI.

RESULTS: The sacroplasty procedure was performed in three female cases with sacral stress fractures resistant to conservative treatment. There was history of minor trauma in all cases. The diagnosis was performed using CT and MRI. The sacroplasty procedure was performed using the short-axis technique. The preoperative VAS score reduced from 8.5 to 2.3 postoperatively.
\end{abstract}

CONCLUSION: It is concluded that sacroplasty is an effective and safe procedure in the treatment of the sacral stress fractures.

KEYWORDS: Hip pain, Sacral stress fractures, Sacroplasty

\section{ÖZ}

AMAÇ: Sakral stres kırıkları nadir görülen, kendini bel ve kalça ağrısı ile gösteren kırıklardır. Bu kırıkların tedavisinde sakroplasti ile iyi klinik sonuçlar alınmaktadir.

YÖNTEM ve GEREÇ: Sakroplasti uygulanan üç sakral stres kırıklı hastanın klinik ve radyolojik verileri incelenmiştir. Ağrının şiddeti VAS ölçeği ile değerlendirilmiş, radyolojik değerlendirmede sakral BT ve MR yapılmıştır.

BULGULAR: Sakroplasti sakral kırığı olan üç kadın hastaya uygulanmıştır. Olguların üçünde de minör travma öyküsü mevcut olup, konservatif tedaviye rağmen ağrı devam ediyordu. Sakral kırıklar BT ve MR incelemesi ile gösterilmiştir. Tanı konduktan sonra kısa eksenli teknik ile sakroplasti yapılmıştır. Olguların preop ortalama VAS skorları $8.5^{\prime}$ ten postop 2.3'e düşmüştür.

SONUÇ: Sakroplasti sakral stres kırıklarının tedavisinde oldukça etkin ve güvenilir bir yöntem olarak değerlendirilmiştir.

ANAHTAR SÖZCÜKLER: Kalça ağrısı, Sakral stres kırıkları, Sakroplasti

\section{Sait NADERI ${ }^{1}$ \\ Hakan ILASLAN ${ }^{2}$ \\ Ahmet ASLAN ${ }^{3}$ \\ Omer Nadir KOC ${ }^{4}$ \\ Turker DALKILIC ${ }^{5}$}

1 Ümraniye Training and Research

Hospital, Neurosurgery Clinic,

Istanbul, Turkey

2,3,4,5 Istanbul Medipol Hospital

Neurosurgery Clinic,

Istanbul, Turkey

Received : 07.11.2009

Accepted : 24.12.2009

Correspondence address:

Sait NADERI

Ümraniye Training and Research Hospital, Neurosurgery Clinic, Istanbul, TURKEY

E-mail : saitnaderi@yahoo.com 


\section{INTRODUCTION}

Sacrum fractures constitute a minor portion of surgical practice. These fractures can occur as a component of acute lumbosacral fractures, or can also occur as fractures related to osteolytic tumors or osteoporotic stress fractures $(12,22)$. While the classical approach for acute unstable sacral fractures is reduction and instrumented fusion, the sacroplasty technique is used for osteolytic and osteoporotic fractures $(4,7,8 ; 10,18,24,26,29)$.

Sacroplasty, which can be defined as sacral vertebroplasty and / or kyfoplasty, was first reported in 2000 for osteolytic tumors $(6,17)$, and was described in detail by Garant in 2002 (9). This procedure is performed under CT $(14-16,19,21,26)$ or C-arm fluoroscopy (11). Rather good results are reported in both osteoporotic $(4,7,8,18,28)$ and tumor-related $(10,24,26,29)$ sacral fractures. The purpose of this study is to report the results of three cases where sacroplasty was performed within the last year and to review the latest information in the literature.

\section{MATERIAL and METHODS}

The charts of the three cases where sacroplasty was performed within the last year were retrospectively reviewed. Common features of these cases were presentation with severe pain in the hips (VAS > 7), lack of benefit from medical and physical therapies and presence of fractures in the sacral imaging studies performed. All cases had stress fracture related to old-age osteoporosis. The clinical picture of all three cases was in line with classical sacral stress fractures.

Sacroplasty was performed in all the cases in the prone position under sedo-analgesia and local anesthesia through the S1 pedicle and using the short-axis technique. All cases were mobilized 2 hours after the procedure and were discharged the next day. Our cases used lumbosacral orthesis for one month following the procedure.

Case 1: A 67-year-old female presented with severe pain in her left hip for the last three months. She could not sit or lie down and could only walk with assistance. It was understood from the personal history that she had fallen down on her hip three months ago. In the physical examination, there was sensitivity with pressure on the left hip. Flexion of the left hip was $4 / 5$ and the power of left extensor hallucis longus muscle was $3 / 5$. The VAS score in the left hip was found to be 9. The lumbar MR examination showed L3-4 and L4-5 spinal stenosis. A stress fracture was found in the right hip in $M R$ and CT examinations of the hip (Figure 1A,B,C,D). A left sacroplasty was performed. (Figure $2 \mathrm{~A}, \mathrm{~B}, \mathrm{C}, \mathrm{D}$ ) The VAS score in the left hip was 3 in the postoperative evaluation. She could walk without assistance after the procedure.

Case 2: A 64-year-old female presented with persistent pain in her left hip for the last two months

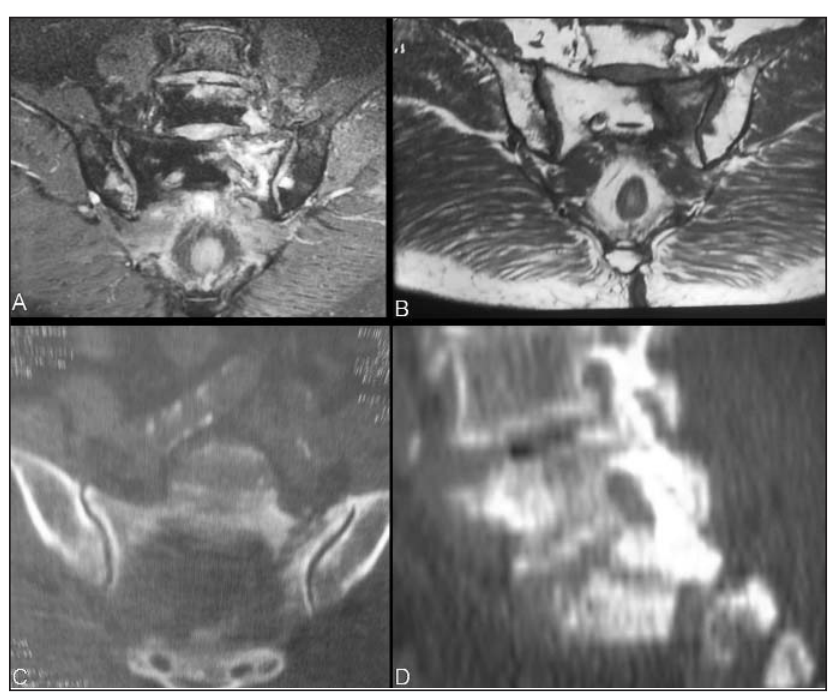

Figure 1: Preoperative radiological images of case 1. (A,B): T2and T1-weighted coronal views of the sacral spine demonstrate left sacral fracture and accompanying medullary edema. Coronal (C) and sagittal (D) CT views of the sacral spine also show the details of the fracture line.

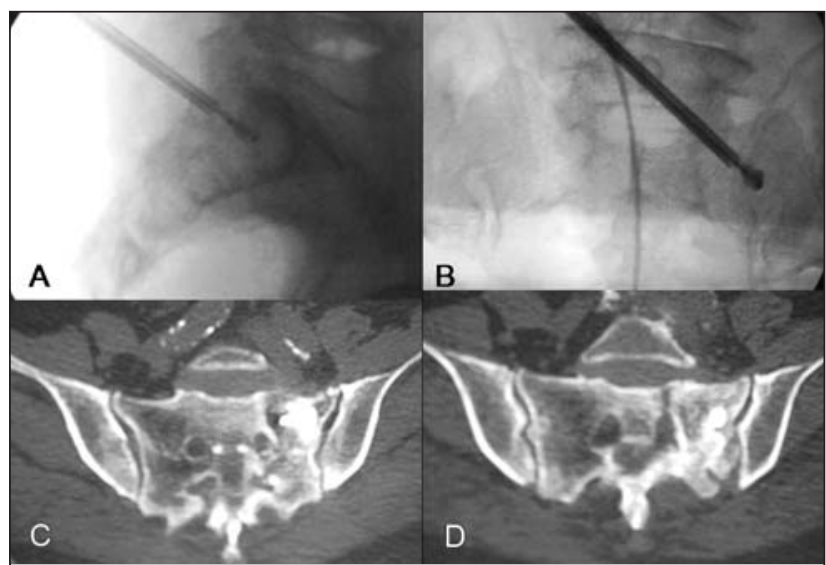

Figure 2: Postoperative radiological images of case 1. $(A, B)$ : show the lateral and $A P$ view of the sacroplasty procedure under fluoroscopy with $C$-arm. $(C, D)$ : Postoperative appearance on $C T$ slices 
that did not respond to medical therapies. Her pain had continued with the same severity since the day she fell. It was found that she was neurologically intact, her left hip was sensitive on physical examination and the preoperative VAS score was 9 . There was a left sacral fracture in the CT and MR examination, and bone marrow edema in the region of the fracture line (Figure 3A,B). Left sacroplasty was performed (Figure 3C,D) because her pain persisted despite immobilization of 3-4 weeks. She was mobilized two hours after the procedure. The postoperative VAS score was 2.

Case 3: A 75-year-old female presented with pain in both hips, with dominance of the right hip that persisted for the last two months. It was understood that she had fallen onto her hip and that her complaints started after that. She was neurologically intact. Preoperative VAS score was 8 . She could walk with crutches. It was seen in lumbar MR examination that there were degenerative changes. It was understood that her pain was attributed to degenerative factors, and she had a 15-day physical therapy with this reason about one month ago; however, she did not benefit from it. A left sacral stress fracture was found in sacral CT examination and osteolytic changes were seen in the right sacrum (Figure 4A). In the hip MR examination of the patient, hypo-intense changes were found in the right sacral wing, and fracture and bone edema were found in the left. Bilateral sacroplasty was applied (Figure 4B). The pain markedly reduced and became VAS 2. She was mobilized in the early preoperative period with no assistance and no crutches.

\section{DISCUSSION}

Results from the three cases presented in this study show that the sacroplasty procedure is effective in selected sacral stress fractures. The sacroplasty procedure was performed for the first time in cases of osteolytic tumor with sacral fracture $(6,17)$. Later, Garant established the details of the technique and described the sacroplasty applications (9). Many studies on this subject were published in the recent years, and details like the technique used (short- or long-axis technique) $(9,20)$, imaging technique used (fluoroscopy or CT) (3,14$16,19,21,26)$, amount of cement injected and presence or absence of balloon use were reported. However, the risk-benefit ratio is still unclear. Biomechanical

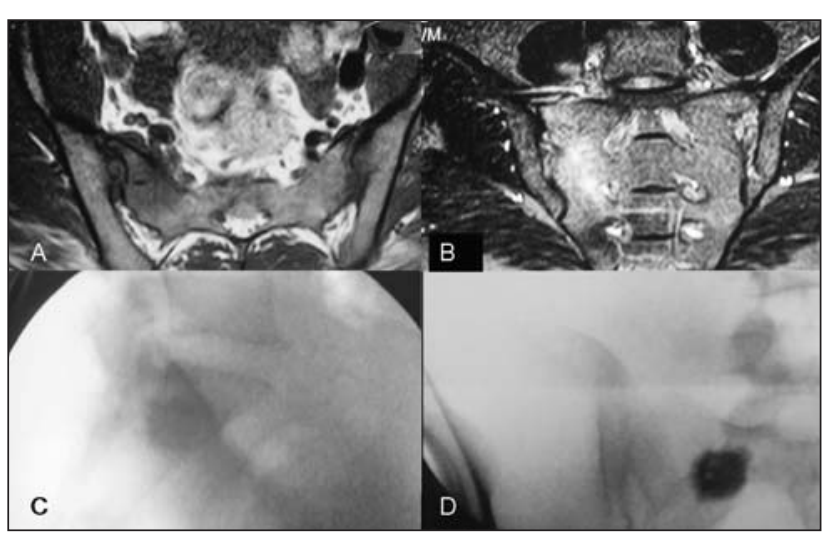

Figure 3: Preoperative and postoperative radiological images of case 2. A and B: Axial and coronal MR images show right sacral fracture in association with medullary edema. C and D: Postoperative lateral and AP sacral radiographs show the appearance of cement in the fracture area.

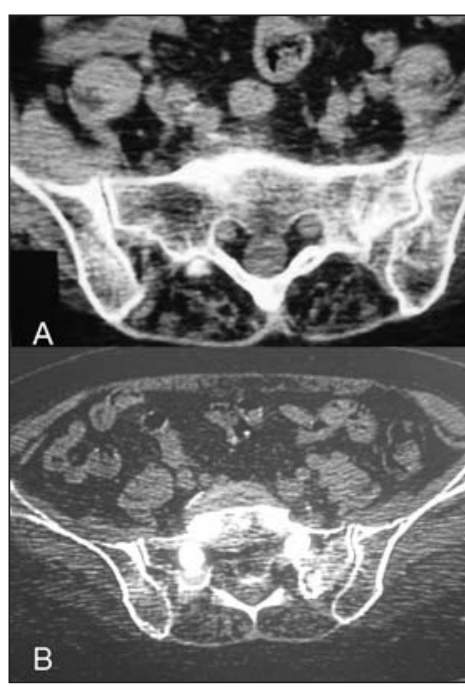

Figure 4: Preoperative and postoperative $C T$ images of case 3: A: Preoperative axial CT view shows left sacral fracture and osteoporotic changes in the right sacral wing. B: Postoperative CT image shows the cement in the sacral wings.

aspects of the procedure have also been the subject of various studies together with clinical studies in recent years (25).

A review of clinical studies on sacroplasty shows that many consist of case reports. In addition, the evidential values of these papers are not very high. In fact, there are no studies with evidence class I, II or III in the literature. The number of studies with follow-up periods exceeding one year was found to be 5 (2). Bayley reviewed 108 cases in different series where sacroplasty was used and found that bilateral sacroplasty was performed on 47 cases. Unilateral sacroplasty was performed on two of the cases presented here, and bilateral sacroplasty was performed on the remaining case. 
The short-axis technique was described in the literature first (9). In this technique, intervention is made through the S1 pedicle towards the wings of S1 $(4,5,14,18)$. In the long-axis intervention described in later years, the injection is made after having access to the canal from S2-3 space lateral to the posterior foramens $(7,8,16,19,21,23)$. While relatively smaller amounts of cement can be injected in the former technique, larger amounts of cement can be injected in the long-axis technique. The risk of entering the foramen is considered to be higher in the latter technique. The amount of cement injected ranges between 2 and $10 \mathrm{cc}$. In cases presented here, 2-5 cc cement was injected to each side with the short-axis technique.

Deen and Nottmeier in 2005 demonstrated the feasibility of balloon-assisted sacroplasty (5). The balloon-assisted technique was also used in our three cases and was found to be feasible and safe.

Whatever the technique used, the VAS score fell from 8.9 to 2.6 in the published papers. Likewise, our cases were mobilized within 2-3 hours in the early period. Our cases benefited from the procedure.

The main complications reported in the literature can be summarized as leakage of cement to S1 or other foramens, and leakage to the sacroiliac joint or to the paravertebral region $(4,5,7,8,11,14,18,20)$. No complications were seen in the cases presented in this study.

Biomechanical studies have shown that sacroplasty reduces the micro movements of the fragments of the fractures $(1,25,27)$.

Finally, it is concluded that sacroplasty is a suitable, effective and reliable choice in sacral stress fractures.

\section{REFERENCES}

1. Anderson DE, Cotton JR: Mechanical analysis of percutaneous sacroplasty using CT image based finite element model. Med Eng Phys 29: 316-325, 2007

2. Bayley E, Srinivas S, Boszczyk BM: Clinical outcomes of sacroplasty in sacral insufficiency fractures: A review of the literature. Eur Spine J 18: 1266-1271, 2009

3. Binaghi S, Guntern D, Schnyder P, Theumann N: A new, easy, fast, and safe method for CT-guided sacroplasty. Eur Radiol 16: 2875-2878, 2006

4. Butler CL, Given CA, Michel SJ, Tibbs PA: Percutaneous sacroplasty for the treatment of sacral insufficiency fractures. AJR Am J Roentgenol 184: 1956-1959, 2005
5. Deen HG, Nottmeier EW: Balloon kyphoplasty for treatment of sacral insufficiency fractures. Report of three cases. Neurosurg Focus 18(3):E7, 2005

6. Dehdashti AR, Martin JB, Jean B, Rufenacht DA: PMMA cementoplasty in symptomatic metastatic lesions of the S1 vertebral body. Cardiovasc Intervent Radiol 23: 235-237, 2000

7. Frey ME, DePalma MJ, Cifu DX, Bhagia SM, Daitch JS: Efficacy and safety of percutaneous sacroplasty for painful osteoporotic sacral insufficiency fractures: A prospective, multicenter trial. Spine (Phila Pa 1976) 32: 1635-1640, 2007

8. Frey ME, Depalma MJ, Cifu DX, Bhagia SM, Carne W, Daitch JS: Percutaneous sacroplasty for osteoporotic sacral insufficiency fractures: A prospective, multicenter, observational pilot study. Spine J. 8: 367-373, 2008

9. Garant M: Sacroplasty: a new treatment for sacral insufficiency fracture. J Vasc Interv Radiol 13: 1265-1266, 2002

10. Georgy BA: Percutaneous cement augmentations of malignant lesions of the sacrum and pelvis. AJNR Am J Neuroradiol 30: 1357-1359, 2009

11. Gjertsen O, Schellhorn T, Nakstad PH: Fluoroscopy-guided sacroplasty: Special focus on preoperative planning from three-dimensional computed tomography. Acta Radiol 49: 1042-1048, 2008

12. Grasland A, Pouchot J, Mathieu A, Paycha F, Vinceneux P: Sacral insufficiency fractures: An easily overlooked cause of back pain in elderly women. Arch Intern Med 156: 668-674, 1996

13. Grossterlinden L, Begemann PG, Lehmann W, Nuechtern J, Schumacher U, Nagel HD, Linhart W, Adam G, Rueger JM, Briem D: Sacroplasty in a cadaveric trial: Comparison of CT and fluoroscopic guidance with and without balloon assistance. Eur Spine J. 18: 1226-1233, 2009

14. Heron J, Connell DA, James SL: CT-guided sacroplasty for the treatment of sacral insufficiency fractures. Clin Radiol 62: 1094-1100, 2007

15. Kang SS, Kim HC, Park JH, Hong SJ, Kim IS, Shin KM: Threedimensional C-arm computed tomography-guided sacroplasty for the treatment of sacral body fracture. Spine (Phila Pa 1976) 34: E 309-311, 2009

16. Layton KF, Thielen KR, Wald JT: Percutaneous sacroplasty using CT fluoroscopy. AJNR Am J Neuroradiol 27: 356-358, 2006

17. Marcy PY, Palussie`re J, Descamps B, Magne` N, Bondiau PY, Ciais C, Bruneton JN: Percutaneous cementoplasty for pelvic bone metastasis. Support Care Cancer 8: 500-503, 2000

18. Pommersheim W, Huang-Hellinger F, Baker M, Morris $\mathrm{P}$ Sacroplasty: A treatment for sacral insufficiency fractures. AJNR Am J Neuroradiol 24: 1003-1007, 2003

19. Sciubba DM, Wolinsky JP, Than KD, Gokaslan ZL, Witham TF, Murphy KP: CT fluoroscopically guided percutaneous placement of transiliosacral rod for sacral insufficiency fracture: case report and technique. AJNR Am J Neuroradiol 28: 1451-1454, 2007

20. Smith DK, Dix JE: Percutaneous sacroplasty: Long-axis injection technique: AJR Am J Roentgenol 186: 1252-1255, 2006

21. Strub WM, Hoffmann M, Ernst RJ, Bulas RV: Sacroplasty by $\mathrm{CT}$ and fluoroscopic guidance: Is the procedure right for your patient? AJNR Am J Neuroradiol 28: 38-41, 2007

22. Thomas EN, Cyteval C, Herisson C, Leonard L, Blotman F: Osteoporotic fracture of the sacrum: Sacroplasty and physical medicine. Ann Phys Rehabil Med 52: 427-435, 2009 
23. Tjardes T, Paffrath T, Baethis H, Shafizadeh S, Steinhausen E, Steinbuechel T, Rixen D, Buoillon B: Computer assisted percutaneous placement of augmented iliosacral screws: A reasonable alternative to sacroplasty. Spine 33: 1497-1500, 2009

24. Uemura A, Matsusako M, Numaguchi Y, Oka M, Kobayashi N, Niinami C, Kawasaki T, Suzuki K: Percutaneous sacroplasty for hemorrhagic metastases from hepatocellular carcinoma. AJNR Am J Neuroradiol 26: 493-495, 2005

25. Waites MD, Mears SC, Richards AM, Mathis JM, Belkoff SM: A biomechanical comparison of lateral and posterior approaches to sacroplasty. Spine (Phila Pa 1976) 33: E 735-738, 2008

26. Wee B, Shimal A, Stirling AJ, James SL: CT-guided sacroplasty in advanced sacral destruction secondary to tumour infiltration. Clin Radiol 63: 906-912, 2008

27. Whitlow CT, Yazdani SK, Reedy ML, Kaminsky SE, Berry JL, Morris PP: Investigating sacroplasty: Technical considerations and finite element analysis of polymethylmethacrylate infusion into cadaveric sacrum. AJNR Am J Neuroradiol. 28: 1036-1041, 2007

28. Whitlow CT, Mussat-Whitlow BJ, Mattern CW, Baker MD, Morris PP: Sacroplasty versus vertebroplasty: Comparable clinical outcomes for the treatment of fracture-related pain. AJNR Am J Neuroradiol 28: 1266-1270, 2007

29. Zhang J, Wu CG, Gu YF, Li MH: Percutaneous sacroplasty for sacral metastatic tumors under fluoroscopic guidance only. Korean J Radiol 9: 572-576, 2008 